\title{
Q Axis Right Axis Deviation
}

National Cancer Institute

\section{Source}

National Cancer Institute. Q Axis Right Axis Deviation. NCI Thesaurus. Code C71095.

An electrocardiographic finding of the $\mathrm{Q}$ axis from +90 to +180 degrees. 